\title{
Book Express: Meaningful access
}

\author{
By Evelyn Greenberg \\ Assistant University Librarian for Public Services \\ Rutgers University
}

Why is it that what you need is always somewhere else? Time is precious, and spending it in transit to "somewhere" else is frustrating. Such is the problem of Rutgers University students and faculty in relation to library materials. Book Express was our solution.

The Rutgers University Libraries are 18 libraries on three campuses. The largest concentration of libraries and students is in New Brunswick where four parts of the University are separated from each other by a river and/or a downtown area. New Brunswick is about 25 miles from the Newark campus and 60 miles from the Camden campus.

The University operates a free bus service to transport students, faculty, etc., around New Brunswick. The University also maintains trucks for "campus mail" between Newark and New Brunswick and between New Brunswick and Camden. The libraries run a delivery van among the New Brunswick libraries. It carries mail, newly processed books, books returned at one library and going back to another, etc.

Until 1985 most of the lending among the libraries was for material needed for Reserve. Patrons within New Brunswick were encouraged to travel to any other library. If they asked for the material to be sent, service was slow.

In late fall 1984, because of unexpected generosity on the part of the state of New Jersey, the University had surplus tuition money and each division was asked for plans to use the money to benefit student life. The University Libraries had been considering solutions to the access problem in New Brunswick for some time and now the prospect of funds to make it a reality galvanized thought.

The plan had to be simple, do-able, well advertised, and reasonably priced. Traffic on the New Brunswick campuses during the day would make any delivery slow. Therefore a scheme for Delivery After Dark, "Let DAD do it!", was first devised. The name was eventually changed to Book Express.

After discussions, brain storming sessions, etc., from many librarians and staff, Book Express was proposed and accepted by University Administration for an approximately $\$ 20,000$ annual price tag. A few hundred dollars was spent on supplies, but the cost of a full-time staff member (about $\$ 15,000$ with fringes) and hourly staff used most of the money. The cost of the use of the library van at night was borne by the libraries.

The twenty-four hour delivery service operates evenings (5:30 p.m.-11:00 p.m.) Sunday through Friday and provides books from the four major libraries in New Brunswick: Alexander Library, Library of Science and Medicine, Kilmer Library, and Douglass. The libraries in Newark (Dana Library) and Camden (Camden Arts and Sciences) benefit since requests for books located at the four New Brunswick libraries no longer require a telephone call but are searched and taken to the intercampus pick-up site six days a week. This improves service to these libraries by at least three days. Book Express is somewhat reduced during Summer Session, Intersessions and Holidays, but does function year round.

Large, heavy duty canvas sacks were purchased for transporting the books from the van to the library, since loading dock areas and hand trucks are not feasible. The service starts at the Alexander Library where the van is parked and where the Newark and Camden requests are picked up. Alexander Library requests are picked up first and, along with those from Camden and Newark, sorted according to the library they are in. Then the route starts. Two complete circuits of the libraries are made so that all requests and answers can be completed.

The patron fills out a simple form and places it in an IN box at any of the participating libraries. The form instructs the user to check an IRIS (online circulation system) terminal first and to only request an item that is not charged out. No double checking of this form is done. We assume that the user knows that he/she will not get material that is charged out and therefore will not ask for it. Also lack of attention to a proper call number, title, etc., will not get the patron the item and that will be the motivation to do it right.

Book Express staff charge available items to a patron called Book Express-Library, the "Library" being where the patron will pick it up. After Book Express staff deliver the material it is put on the hold shelf at the library. If an item is not found by the Book Express staff, an appropriate answer is checked on the form. The form is put in the ANSWER box and the patrons told to check that box by library staff if the requested material is not on the hold shelf for them. Library staff do not check the answers. If the patron wants to pursue the rea- 
son for the non-delivery of a book, the Book Express form suggests consulting the library staff.

Book Express has been a huge success. Even so, some people seem not to know about it, and our efforts at publicity are continuing. The utilization of the service has meant a dramatic rise in resource sharing among the Rutgers libraries. In 1985/86, a total of 6,430 requests were filled and 10,494 in $1986 / 87$. This represents a $62 \%$ rise in material handled. There was also a rise in the fill-rate from
$70.61 \%$ to $72.46 \%$.

The success of the plan has led to one that was more ambitious. We requested special funds from the University for Copy Express. This program piggy-backs on the Book Express delivery and has much more impact on patrons in the sciences where the use of journal literature is dominant. Copy Express is also more expensive, includes two more libraries, and promises a three-day delivery time.

\section{Letters}

\section{CD-ROM}

To the Editor:

A few of the statements about video images in "CD-ROM: A Primer," by Karen A. Becker, C\&RL News, July/August 1987, were puzzling and possibly misleading. The "most economical format for recording still pictures" is laser optical reflective video disk, not digitally encoded video disk. It is certainly possible to encode digital data on video disk (as the National Agriculture Library did with the Pork Industry Handbook); it is also possible to digitize video signals. But the most common and economical approach for recording motion pictures, still pictures, or a mix of the two is still the basic video disk.

The Library of Congress has made several types of optical disks, including a still picture video disk of selected collections in the Prints and Photographs Division, and it is often difficult for the nonspecialist to distinguish between the analog video disk and digital storage systems.-Helena Zinkham, Optical Disk Cataloger, Prints and Photographs Division, Library of Congress.

\section{Online searches}

To the Editor:

Please note that in her article, "Charging for Online Search Services in Academic Libraries," Margaret L. Breen misleadingly quotes from our study, "Report of the Study Group on Electronic Access to Information." Breen states that "Such training alone comes to an estimated $\$ 1,500$ to $\$ 2,000$ annually per librarian." The figure stated in our report was an annual cost for all database searchers, not each of them. We wish we could afford such largess in keeping our searchers current, but of course we cannot. Our study is available as ED254250 for those who wish more information.-Sandra Leach, Database Searching Coordinator, University of Tennessee, Knoxville.

\section{ACRL continuing education scholarships}

ACRL will offer two free-tuition scholarships for ACRL continuing education courses held prior to the ALA Annual Conference in New Orleans.

The applicant must:

1. be a member of ACRL by the application deadline (December 1, 1987).

2. hold a master's degree in library science from a program accredited by ALA.

3 . have at least three years experience in a library prior to the application deadline.

4 . be currently employed in a library in a position generally accepted as "professional," as defined by their institution.

5 . have not previously been granted and utilized this scholarship.

6. have given evidence of professional growth as indicated by committee work, membership in pro- fessional organizations, etc.

7. have the prerequisite background to benefit from the course selected.

Awards will be made based upon:

1. evidence of commitment to librarianship as a profession.

2. potential benefit to the individual and the profession.

3. relevancy of the course requested to current position or clearly identified career track.

4. financial need.

5. service to ACRL, ALA, or the wider profession.

For additional information about these free scholarships contact ACRL, 50 E. Huron St., Chicago, IL 60611. 


\section{Other indexes just SCRATEII the surface.}

The Arts \& Humanities Citation Index ${ }^{\mathrm{TN}}$ provides a scope and depth of coverage most other indexes can't begin to match. Using the $A \& H C I^{\mathrm{T}, \mathrm{I}}$ you can find information about original works-articles, books, films, plays, paintings, and more. You can locate articles that review or reference those original works. And you can use information you already have-like names, words or subject areasto find other articles related to your subject areas.

So while other indexes enable you to find information only when you have very specific details to begin your search, the A\&HCI goes beyond the surface to give you more options when searching the arts and humanities literature. To find out more about the $A \& H C I$ and other arts and humanities services offered by ISI ${ }^{\circledR}$, mail this coupon today.

员员 Institute for ¿ك Scientific Information

Customer Services Department, 3501 Market Street, Philadelphia, PA 19104 U.S.A.

Telephone: (215)386-0100, ext. 1405, Cable: SCINFO, Telex: 84-5305 Telecopier: (215)386-6362 European Branch: 132 High Street, Uxbridge, Middlesex UB8 1DP, United Kingdom Telephone: 44-895-70016, Telex: 933693 UKISI

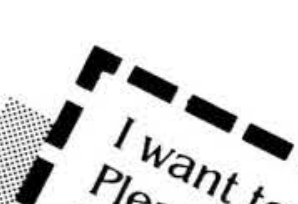

